\title{
The Science of Public Speaking from a Western Philosophical Perspective: A Focus on Female Speakers
}

\author{
Nodhar Hammami Ben Fradj \\ Faculty of Arts and Humanities of Kairouan, University of Kairouan, Kairouan, Tunisia
}

Email address:

nodharhammami@yahoo.com

\section{To cite this article:}

Nodhar Hammami Ben Fradj. The Science of Public Speaking from a Western Philosophical Perspective: A Focus on Female Speakers. Arabic Language, Literature \& Culture. Vol. 4, No. 3, 2019, pp. 60-67. doi: 10.11648/j.allc.20190403.13

Received: September 21, 2019; Accepted: October 14, 2019; Published: October 24, 2019

\begin{abstract}
The paper relies on certain key modern Western theorists to deal with public speaking as a science and as an art while putting a special focus on female speakers. It studies the techniques of public speech and reveals the sources of power that allow an oratress to manipulate and persuade her receivers. It also states the limitations of woman's public confrontation with a mixed audience. The point is that the gender of the female speaker may weaken the impact of her performance on her targeted addressees because of the hostile societal view towards women as leaders, the view of the female body as a source of delight by a male audience and as a generator of money by a capitalist sponsor. However, women performers can even deliver more influential verbal orations than males if they use their own female qualities and adhere to a set of tools such as rhetoric, body language, feminine manners, histrionic character, etc. A powerful public address can help woman resist commodification in a capitalist culture and objectification in a patriarchal society.
\end{abstract}

Keywords: Female, Public, Speaker, Power, Performance, Politician

\section{Introduction}

The Greek scholars Plato, Aristotle and Socrates sowed the seeds of the Western classical rhetoric theory to study the influence of the public speaker on his audience. The public speaker strives to inform, educate, motivate, persuade or entertain his listeners in a certain political or social or cultural or business context. The usage of language as a means of persuasion was one of the main concerns of the classical rhetoric theory. Rhetoric has been considered as an art, especially in the fields of politics, religion and law. The speaker, the speech and the listener are the three elements identified by Aristotle in his Rhetoric for the realization of an effective communication. Five canons of rhetoric are identified in the Roman philosopher Cicero's first-century work Rhetorica ad Herennium which contained four books that described the rhetorical approach then. These canons are: first, the invention (inventio) as a method used to find out arguments; second, the arrangement (disposito) which is considered as the system used to arrange those arguments; third, the style (elocutio) which refers to the mastery of stylistic elements; four, memory (memoria) which permits memorization and improvisation; and finally, the delivery (actio) as a reference to the crafting and delivery of speeches.

In ancient Greek and Rome, the art of rhetoric was based on oratory as the process of giving a public performance in philosophical, political and legal matters to a live audience. George Kennedy defines classical rhetoric as: " that theory of discourse developed by the Greeks and Romans of the classical period, applied in both oratory and in literary genres, and taught in schools in antiquity, in the Greek and western Middle Ages, and throughout the Renaissance and early modern period [13]." It was an important skill in both public and private life aiming at persuading a given audience in a particular field; Peter France argues that "the aim of rhetoric is to make persuasion easier by providing a body of time-honoured rules; these rules are not arbitrary but a codification of 'nature', of the natural means of persuasion [9]." Oratory was a science and a field of study; during the Middle Ages and the Renaissance, it had definitive rules and models which were emphasized as a part of liberal arts education. In the late nineteenth century, as the American college system moved from small schools to a large set of universities with distinct academic disciplines, traditional rhetorical studies originated the field of composition studies. In traditional terms, rhetoric was concerned with verbal 
orations or public speeches, whereas in modern and academic terms, both rhetoric and composition studies concern themselves with the expression of ideas and the attempt to persuade.

In the present paper, I intend to focus on the nature and rules of public speaking and verbal orations, and the performer's sources of power while reserving a particular attention to women as successful public performers whether as politicians, preachers, or artists. The work does not give interest to the degree of sincerity or authenticity of public speaking, but rather to the mediums used by the female speaker to leave a positive impact on the targeted audience and achieve the desired effect. I use some Western philosophers' concepts and views in order to study the rules of public speaking and apply them to women orators. The paper studies as well the limitations of the female public performances and the dangers they encounter in society because of their gender. It addresses questions like: does it make a difference if the speaker is a woman? Can she persuade her audience in the separate fields of religion, politics, media, and art? What are the skills possessed by a woman which grant her with power and can she be skillful in the art of persuasion? Can the male gaze at women speakers disorient the act of reception and distort woman's political and religious messages?

\section{The Techniques of Public Speaking}

A female addresser does not only prove to be able to manipulate female addressees, but succeeds also in targeting mixed audiences. The spirit of solidarity and sisterhood is not the reason behind the success of woman's public addresses, for women thrive in the fields that equally appeal to male and female citizens. Woman makes use of the art of speech in order to win the admiration of people and gather their voices. She manifests extraordinary aptitude for public speaking, persuasion and manipulation. In politics, female politicians and leaders have succeeded all along history in gaining popularity. Among modern political public performers, it may be listed: Benazir Bhutto (Pakistan's prime minister from 1988 to 1990), Indira Ghandi (India's prime minister from 1966 to 1984), Margret Thatcher (the prime minister of the United Kingdom from 1979 to 1990), Gloria Macapagal Arroyo (Philippine's president from 2000 to 2010), Angela Merkel (the first female chancellor of Germany elected in 2005), Teresa May (the prime minister of the UK and leader of the Conservative Party who assumed office in 2016 till 2019), and Hilary Clinton (the US first lady and candidate for the 2016 presidential elections). Other examples of female public speakers are activists in the civil society, government officers, advisors and representatives, lecturers, actresses, media consultants, TV commentators, presenter hostesses, broadcast media presenters, Christian ministers, curates, and pastors, Muslim female murshidats (religious teachers), akhoonds (the standard Chinese word for imams or prayer leaders and lecturers in mosques), leaders of congregational prayers, and preachers (like the American Amina Wadud, Pakistani-Canadian Raheel Raza, South African Shamima
Shaikh, and other Turkish preachers, etc.).

In order to achieve success in the delivery of their speeches, women as public speakers need to comply with a set of techniques that should be added to their physical features, charismatic and histrionic characters. Performance refers generally to an event in which one person or a group of people behaves in a particular way for another group of people (the audience). The performer is "framed by 'special settings' such as theatres or lecture halls [14]", podiums in a political context and minbars or pulpits in a religious milieu; these settings give the speaker a sense of formality. However, in all of these contexts, the performer needs to be theatrical so as to convey the message and affect the receiver whereby presentation and appearance substitute for policy and principle. In The Power of Address, Dick Leith and George Myerson identify theatricality as "the performer's technique" which consists in the "bodily operations" that are added to the text of the performance or the script to convey the intended message while using "voice, posture, gesture and face [14]."

In the political domain, the discourse of politicians should be powerful and convincing despite its deceiving or theatrical nature; in many cases, it conceals the personal intentions of leaders, political interests of the government or political parties, and real motives of the oration itself. In "Defining Political Performance with Foucault and Habermas: Strategic and Communicative Action," Jon Erickson defines "theatricality" and "ideology" as "examples of a rhetorical apparatus that has the ability to efface its own performance techniques in order to present the illusion of a truth dramatically to its audience [6]." Erickson's argument is that both theatricality and ideology have the power to convince or persuade, though they do it differently: theater by exposing conflict and politics by striving for harmony. Political performances involve both theatricality and ideology where the performer uses language, body, face and presence as theatrical mediums to publicize his ideology. Women tend to be inherently skilled at using expressive body language whether to aggrandize their communications or to add to them the dramatic flavor and make them appear more appealing, dynamic, vivid, lively, and influential while men do not seem to be doing that at all; generally they prefer verbal language to gestural language.

An adept theatricality is the performer's key to the hearts of people; orators must master the art of performance through which they seek to be believed and trusted. Therefore they endeavor to make the audience believe in their sincerity; they strive to appear as much spontaneous and natural as they can. Generally, the sincerity of the performer stimulates sincere reactions of the audience; not to lose her credibility and trust, the female speaker attempts to look unpretentious and unprompted. Women may appear more enthusiastic and emotional in their public speeches than men, which makes them touch the hearts of the receivers. The speaker tends to play her role naturally while acting that she is not acting; she should be naturally theatrical. And once the addressee feels that sincerity, the message gets through easily and efficiently. Leith and Myerson assume that " $[t]$ here is a feeling that 
political oratory cannot, and ought not, to be taught, because 'good' public speaking should be spontaneous rather than contrived. Spontaneity is seen as a guarantee of something often called 'sincerity', the authentic expression of one's true, unitary, individual self [14]."

In her book Acting Naturally: Victorian Theatricality and Authenticity, Lynn Voskuil argues that Victorians consider themselves as "authentically performative [22]; two inherently paradoxical terms which reflect the Victorian personal, public, and national identity. Despite the Victorian campaigns for antitheatricality, the Victorians shared an emotional commitment to authenticity, reinforced rather than threatened by their fascination with acting and performance. Vosquil maintains that the Victorian adherence to the culture of sincerity did not annihilate their admiration of performance. She studies the central paradox in "Victorian England's perception of itself as 'authentically theatrical' [22]." She explores the Victorian theories of "natural acting," through her study of nineteenth-century public spectacles that attracted the audience and proved the failure of antitheatrical crusades. Victorian attachment to the theater created in their minds criteria to judge the best performers according to their authenticity, whether it be actors or politicians like Prime Ministers or even British subjects.

Performed authenticity, or authentic performance are interchangeable expressions that show acceptance of theatricality as long as it is connected with authenticity. When the performer - whether a politician or an actor- displaces his real self and identifies with his new public role, he tries to preserve his authenticity. Consequently, when the audience assimilates the natural acting of the performer, the boundaries between theatricality and authenticity get undone; it is an illusory fact which converts the audience themselves into performers. About Victorians, Vosquil argues that:

Victorian sympathy involved an imaginative transfer of the emotional self, a projection of one's own emotions into the situation of another. While the sympathetic imagination might function more easily when the situation in question was similar to one's own, the presumption was that sympathy had the power to transcend even the most intractable differences... that separated individuals [22].

Like black preaching, feminist oratory plays on the feelings of the audience, especially if they belong to the same category of the performer, black or female. A political speaker is "like a preacher, he tries to cultivate a reassertion of values that he assumes many of them share [14]." The performer's power of knowledge conflates with her discursive power to influence her audience; "influence" itself is seen as a means of power.

When Erickson insists that theatricality is a mediating process and that rhetoric is always an aspect of argument, he sets up the foundations for his analysis of the political positions taken by Michel Foucault and Jurgen Habermas; he observes how their political views relate to theatricality. Foucault's "monological argument" or "strategic action", with its ideal of self-invention and statement that no one should attempt to speak for the other, denies what theater and political platforms do. On the other hand, Habermas excludes strategic action from the political in his advancement of "dialogical communication" or "communicative action" which involves cooperative action undertaken by individuals, based upon mutual deliberation and argumentation. Habermas's "communicative action" functions as a more general alternative to public discourse; communication in this context means "not merely sharing what people already think or know but also a process of potential transformation in which reason is advanced by debate itself [5]." Erickson believes that "Habermas is wrong to exclude Strategic Action altogether from the political scene in which Communicative Action has pride of place. Both forms of action are necessary for political change to occur and for formerly excluded voices to attain a degree of parity in political discourse and decision-making [6]."

In his essay "Foucault and Habermas", David Ingram argues that "communicative action' must incorporate something like 'strategic action' in Foucault's sense of the term [12]." Like Erickson, he shows that political performance should encompass both strategic action, as related to ideology and tactics, and communicative action, as pertaining to rhetoric and argumentation, thus public participation or theatricality. Political performers could profit from an integrated approach that incorporates Foucault's strategic analysis into the framework of deliberative democracy. If we take the example of feminist activists who organize mobilizing speeches in public halls, we find that the spokeswomen of these feminist organizations follow in their public addresses a certain strategy that is prepared beforehand; their speeches are performed scripts. Joining strategy and communication is therefore necessary to guarantee the success of reception. It is by the mediation of a good orator that the tactical action will be accomplished.

Habermas thinks that a strong civil society, as a network of voluntary associations, is necessary to realize a strong democracy and to base citizenship on discursive participation. In his book The Structural Transformation of the Public Sphere, Habermas underscores the role of the public sphere as a way for civil society to articulate its interests while defining the public sphere as the sphere of private people who join together to form a "public". In the course of his examination of publicity as originated in the eighteenth century, Habermas also notes the development of independent institutions into organs of public authority in big cities, which makes them opposed to the state: "Elements of occupational status group organization, to the degree that they were already in the urban corporations and in certain differentiations within the estates of the land, developed into the sphere of 'civil society' that as the genuine domain of private autonomy stood opposed to the state [11]."Thus forming feminist associations, for instance, is a fundamental act of citizenship since it is directed at the creation of social equality which is not provided by the state. Habermas approved of feminist organizations in order to "free politics from the iron grasp of the state, which by virtue of the long denial of the franchise to women and their rare status as public officials, effectively defined the public in masculine terms [19]." He considers the access to public life open to all 
citizens and appeals for woman's ascension into politics.

Yet while Habermas asks for discourse and consensus, Foucault only recommends a focus on conflict and power relations as the most effective point of departure for the fight against domination. By entering into a debate with the oppressor, feminist organizations for instance, not cultivating understanding or reaching consensus, follow another strategic action relying on rhetoric to mobilize the categories belonging to their group whereby issues have made their way onto public agendas through power struggles and conflict rather than consensus. From a Foucauldian perspective, to find a consensus is to suppress conflict and thus to suppress freedom, for conflict is part of freedom. Foucault focuses on the eternal conflict between the state and individuals and between the different classes of society.

The creation of the feminist organizations is considered as a deviance since it does not serve the ends of those in power. Woman's activism has been seen as a transcendence of customs and morality which have been modeled in favor of the traditionally superior sex in what Foucault calls "the normalizing society [7]." The search for sexual equality in society blurs the boundaries between the political and the cultural, given that the authority or government breeds essentialist theories, as cultural constructs, and thus exerts power on the female sex. In strong civil societies, associations criticize and attack the authority, resulting usually in a perpetual political conflict rather than a public consensus. The belonging to left- wing politics, for instance, should not only depend on discourse and consensus in public life but also on conflict as a tool to gain power. Political parties and the civil society have official speakers or spokesmen who are selected for their oral competence and talent in public speaking. The gained popularity of the persons occupying that preaching position is usually projected onto the organizations to which they belong. In a word, the fate of political movements is determined by individuals. Their success or failure is dependent on the skill of their spokesmen at gaining sympathy and admiration.

\section{The Sources of Power for Public Performers}

Techniques such as theatricality, body language, seeming sincerity, feigned authenticity, planning, tactical strategies, opposition to the main stream, search for consensus and focus on the conflictual relations become more efficient if the speaker has a number of assets that can help him/her reach the desired effect. The following subpart offers a study of the sources of power which contribute to the acceptability of the public address and assist in cultivating the attention of the targeted audience. If power refers to a person's or a group's ability to control others in the general way, the means of control vary to include political, religious and social positions, wealth, knowledge, language, direct and indirect influence, personal charisma, and celebrity.

People who represent the authority or group leaders are the most evident category which is authorized to use a downward form of power to influence subordinates. R. P. French and Bertram Raven ${ }^{1}$ describe this type of power as a positional or legitimate power "which stems from internalized values in $\mathrm{P}$ which dictate that $\mathrm{O}$ has a legitimate right to influence $\mathrm{P}$ and that P has an obligation to accept this influence [10]." Leith and Myerson define public performances as "privileged acts of utterance, ones which... attract a level of attentiveness not accorded less focused kinds of interaction. Part of this privileging derives from the status of performers themselves [14]," then add that "[f] ormally institutionalized roles such as that of the preacher or the lawyer derive much of their status from the authority of those institutions [14]." Reversibly, if citizens or members of political groups influence their leader to take certain decision, for example, the power is said to have an upward destination. Opposition, for example, acts against the legitimized power of the government and creates instead a divergent movement whose members and spokesmen aim at creating a political change. They use their membership to twist the balance of power, through public speeches whereby they exert on their audience a positional power to brainwash them. Change, according to French and Raven, includes changes in behavior, opinions, attitudes, goals, needs, and values; they define it as "any alteration of the state of some system over time [10]."

In the same vein of the positional or legitimate power, preachers are seen as trusted instructors of religion: male imams are authority figures who are considered by common people as a source of knowledge. When it comes to the modern trend of female murshidats, they lose some of the authority of their position because of their sex. However, if they perform a decent sermon which displays a deep grasp of the Islamic rules and a convincing argument together with rhetoric, including examples from the listener's daily life, they could be trusted preachers of Islam. Amina Wadud, the American scholar of Islam has invaded the public field by delivering a Friday sermon in cape Town, South Africa in 1994 and leading Friday prayers for mixed-gender congregations in the United States, merely to substantiate the idea of equality and justice in Islam. Despite the social protest and bomb threats Wadud received, she has become a popular figure and an unbeaten murshida ${ }^{2}$ owing to her eloquence and fluency, and the argumentativeness and persuasiveness of her discourse. Today, she stands on an equal footing with wide-reaching male preachers like the Indian Zahir Naik, the American Yusuf Estes, the Zimbabwean Ismail Menk, the American Abu Mohamed Khaled Yasin, the Jamaican Abdullah Elfaisail, and the Egyptian Amr Khaled.

Social class and material wealth are also sources of power which allow noble and upper classes to acquire superior positions in society. Well-off people, whether bourgeois or criminals, have the means to manipulate others; money is here a

\footnotetext{
1 In "Bases of Social Power", French and Raven identify five categories of power: 1. Positional power, 2. Referent power, 3. Expert power, 4. Reward power, 5. Coercive power.

2 An Arabic word which means a female preacher of Islam, teacher and advisor, spiritual and religious leader.
} 
substitute for natural gifts. That is why wealthy members of political movements pay for campaigns led by gifted speakers. If they do not have the talent of speaking, they exert power on citizens by providing their parties with liberal donations to funds designed for the diffusion of certain ideologies or political opinions. They stand behind the scene and manipulate the public indirectly while assigning skillful public speakers for the movement. That assignment is a reinforcement of superiority whereby money becomes the sole means of control. Remunerated participation of public speakers puts forth what French and Raven later refer to as "reward power" which “depends on O's ability to administer positive valences and to remove or decrease negative valences [10]."

If we move on to more abstract means of control, we may start with knowledge. In Discipline and Punishment, Foucault analyzes the link between knowledge and power, saying:

We should admit rather that power produces knowledge (and not simply by encouraging it because it serves power, or by applying it because it is useful); that power and knowledge directly imply one another; that there is no power relation without the correlative constitution of a field of knowledge, nor any knowledge that does not presuppose and constitute at the same time power relations. These 'power-knowledge' relations are to be analyzed therefore, not on the basis of a subject of knowledge who is or is not free in relation to the power system, but on the contrary, the subject, who knows, the objects to be known and the modalities of knowledge must be regarded as so many effects of these fundamental implications of power-knowledge and their historical transformations [8].

Foucault uses the term 'power/knowledge' to signify that power is constituted through accepted forms of knowledge, scientific understanding and 'truth'. He also associates common knowledge with belief systems generating views that are accepted by the majority of people; within such a belief system or "discourse," ideas become normalized truths. The word "discourse" is pointedly defined by Emile Benveniste in his essay "Tense in the French Verb" in the following way: "Discourse must be understood in its widest sense: every utterance assuming a speaker and a hearer, and in the speaker, the intention of influencing the other in some way. It is primarily every variety of oral discourse of every nature and every level, from trivial conversation to the most elaborate oration. But it is also the mass of writing that reproduces oral discourse or that borrows its manner of expression and its purposes [2]." When people defy those belief systems, in another process of knowledge, they acquire power; Foucault insists that without resistance, power is absent. Change may only happen when a new counter-discursive element begins to receive wide attention through the means of communication. The opposing wing's resistance to the system through the rejection of that common knowledge and reliance on particular awareness of the unfairness of the system is an individual knowledge which can be publicly injected in society, entailing power in turn.

Intellect is also an aspect of knowledge and thus a source of power. In his book Powershift: Knowledge, Wealth, and Violence at the Edge of the $21^{\text {st }}$ Century, Alvin Toffler [20] identifies the relationship between the three main forms of power: violence, wealth and knowledge or what he refers to in the second section of the first part of the book as muscle, money and mind. He argues that the intellectual power or the power of mind is a tactical or strategic superiority whereby the subject with power manipulates the subject under power. Public addressers derive their power from their political maturity and social awareness which make them assume the role of public champions. The audience trusts intellectual speakers who are experts or degree owners rather than common speakers. In politics, female intellectuals can be accepted as good orators whose intellect and rhetoric are twinned with emotionality. In religion, female murshidats influence people if they are scholars in Islam or other religions, and have degrees in theology and religious studies. In business, female representatives or advertisers of marketed products are more trusted if they are eloquent intellectuals than common representatives. In the broadcast media, female presenters and commentators are usually successful if they are intellectual.

Language is another source of power: in linguistics, performative acts are types of authoritative speeches. When uttered and repeated, they carry out a certain action and exhibit a certain level of power; these statements must be used consistently to exert power. Performativity ${ }^{3}$, as a means of power, is used by some feminists in the analysis of gender development. In Bodies that Matter: On the Discursive Limits of "Sex", Judith Butler focuses on the performativity of sexual identity, showing that there must be a line of demarcation separating gender as a performative ideal and sex as a material existence. She insists on "the understanding of performativity not as the act by which a subject brings into being what she/he names, but, rather, that reiterative [emphasis added] power of discourse to produce the phenomena that it regulates and constrains [4]." Thus, performativity represents the power of language in determining our political commitment and controlling our behavior. Political addresses are also performative, aiming at cultivating people's approval of certain ideologies, and their reiteration is an exertion of power. Repetition is a technique of propaganda that helps in the process of understanding which may lead to conviction. Some leaders, in the frame of political campaigns, restate their ideas about democracy, freedom of the press, new plans, providing social remedies, solving the issues of unemployment and poverty, etc. in a process of preaching for their parties. If these ideas are rejected or ridiculed at the outset, especially if the orator is a woman, they can become thinkable and convincing after that strategy of repetition. The power of knowledge meets with the power of language in public performances to manipulate masses.

Another aspect of power in language is persuasion, which can be direct or indirect. A person can be indirectly persuaded by another person's ideology or way of life, but if a direct address, a dialogue or an oratory are performed, using eloquence and

3Performativity is a term derived from the speech act theory developed by J.L. Austin who refers to performative utterances as situations where saying something is doing something. 
argumentation, the desire to influence others becomes more evident. As Nikitina claims, "It is not enough to talk in front of a group of people be a brilliant public speaker. Your goal should not be limited with informing your audience or expressing your thoughts publically, but to changing emotions, actions, and attitudes, and to leaving your listeners moved by the words and touched by their meanings [18]." Leith and Myerson employ the term "rhetoric", to refer to the power of persuasion, under the more general notion of performance used in "the physical sense of a flesh-and-blood speaker addressing... the tangible forms of a real audience [14]." The speaker needs to have a good command of language, so eloquence is an art and the performer's artistry is his fountain of power; art and power become radically entangled. If a public speaker lacks eloquence and possesses knowledge, he generally fails to persuade. In case the speaker does not have the power of language, he risks being in a position of weakness and the audience will exert power on him instead. If the speaker is a woman, things may become worse, for if a female public performer does not have the speaking faculty and fails to charm her audience with eloquence and argumentation, she may even be ridiculed and will absolutely lose the game. The inarticulateness of female campaigners, advertisers, presenters, murshidats, lecturers, academics leads to the failure of their performance and will hence be condemned for their gender. By being artful in her use of language, a female speaker can erase the prejudices about her gender and impose herself as a reputable performer rather than merely a woman.

Steven Lukes considers influence as a technique used by power structures; in his book Power: A Radical View, he outlines the dimensions through which power had been theorized and refers to the influences exercised by formal institutions and to informal influences which can be personal or individual [15]. Believing in the power of social influence, French and Raven also think that social influence can be "produced by a social agent, $\mathrm{O}$, where $\mathrm{O}$ can be either another person, a role, a norm, a group or a part of a group [10]." Moreover, influence is seen as a source of power if it brings about desired outcomes. We can rely in this context on Keith Dowding's theory of Rational Choice where people can be modeled as "actors" who choose from a "choice set" of possible actions in order to achieve desired outcomes. This type of power is labeled as "outcome power" to refer to "the ability of an actor to bring about or help bring about outcomes [16]." A woman is capable of using imagination even more than man, which makes her influence her audience. Fancy is an individual tool of influence; it boadens the speaker's field of power and is effective on the platforms because it invites the imagination of the receiver. The desired outcome can thus be sensed through the interaction of the addressees with the lecture or speech. Leith and Myerson draw on the importance of the audience's applause "without which the oration could not be said to be complete [14]." It echoes the performance's success and the performer's acceptability by the audience. The durability of the performer's career depends on the audience's ongoing encouragement and positive reinforcements.

What French and Raven classify as "referent power" refers to the ability of an individual to attract others through his charisma
[10]. Charisma is defined as "a personal magic of leadership arousing special popular loyalty or enthusiasm for a public figure (as a political leader) [17]." Lukes distinguishes between two types of power: active power, which involves the performance of action, and inactive power, which "can derive from powerful agents' properties rather than from their actions, as with the power of attraction. Charismatic power, like magnetism, exemplifies this (though in reality charismatic leaders usually work hard and with skill to achieve their effects) [15]." For female speakers, the power of charisma is one of their central mediums of communication and effective tools of influence. Certain artists, actresses, leaders, presenters or even preachers and murshidats possess the magical power of charisma that makes their speeches kind of mesmeric gesticulations. The female speaker's charisma emanates not only from certain magnetic physical features but also from either her serene or zealous manners on the stage. These qualities initiate the desire of the audience to identify with the performer and gain satisfaction from being an accepted follower, which is to the credit of the advocated ideology. Some women are expert in magnetizing their audiences on account of their charisma, a quality which endows them with the power of "expertness" as coined by French and Raven [10].

Charisma entails celebrity which is, in turn, another source of power; individuals get influenced by the manners, speech, and ways of dressing of famous politicians or popular actors. Leith and Myerson claim that "the star is the object of constant attention; people are encouraged, furthermore, to see every gesture, vocal mannerism, and detail of dress as an aspect of a unique individuality rather than as components of a performance role [14]." From their first talks, women speakers can be admired and take therefore the track of fame, which would make them more influential in their ensuing speeches. They can be respected simply because of their celebrity and reputation. The audience can also enticed by the performer's photographs and campaign as the first step of conviction.

\section{The Perils of Woman's Public Exposure}

However, the principle of publicity, exemplified by such cultural forms as advertising can harm woman's public speech and grind her in the mill of capitalism and patriarchy. The Advertizing has been installed at the center of the modern cultural experience; it is a vital medium of social exchange and a modern phenomenon associated with the great new force of mass marketing. Despite its materialistic aspect, it becomes an inescapable reality. The vehicles for the new industry were the social media, television, videos, and magazines, receiving their chief source of revenue from advertisements. Consumptive readers are invited to be viewers - and consumers- of female spectacles. The posters and photographs of female public speakers in the frame of political elections or cultural activities are used to advertize for public events. That reality, resembling the Hollywood stars photos, has constituted the star image of some politicians, religious 
figures, artists, etc. The star photography is seen in a direct relation with exhibitionism since it brought woman's beauty, body and femininity into play. What cannot be denied is the juxtaposition of art and politics, or even religion and merchandise, femininity and consumption and the fact that exhibitionism and capitalism have created a dominant form of exchange where "the commodity and the spectacle would now go hand in hand [21]."

Public speeches are personalized since a representative of a political movement can turn into a media star, a fact which weakens the communicative and argumentative pattern of her public discourses. In The Structural Transformation of the Public Sphere, Habermas deals in part with the impact of the media on the communicative action [11]. He thinks that rational-critical debate had a tendency to be replaced by consumption and the shared critical activity of public discourse had been replaced by a more passive culture consumption. Habermas critiques mass culture, believing that consumer culture would remove the ground for communication: "In the realm of mass media, of course, publicity has changed its meaning. Originally a function of public opinion, it has become an attribute of whatever attracts public opinion... Sometimes the public appears simply as that sector of public opinion that happens to be opposed to the authorities [11]." These conditions make the female public speaker grow within a hostile entourage which objectifies female orators and reduces them to gendered subjects in lieu of accepting their ideas and listening to their arguments. Female preachers, religious lecturers and imams are thrown out because of their sex; people repudiate them as a source of information, based on the antifeminist assumption that women are imperfect men and that they are forgetful, unreliable, incompetent and inferior.

Consumption becomes feminized and intellectual women turn out to be preys at the hands of capitalism whether in the context of electoral campaigns or coaching and training sessions, public shows, TV interviews, etc. Ideologies, political opinions, religious knowledge become a kind of spectacle, especially if they are spoken out candidly and bravely by female speakers; Helen Tookey rightly puts "there was a strongly feminine inflection to this new consumerism and to the commodified, spectacularized culture of modernity [21]." Women are stereotyped as creatures of consumption par excellence and men are positioned as sanctioned consumers. Beneath woman's bravery in expressing her ideas lurk the dangers of promotion and advertisements and the commodification of female speakers who risk losing their power of influence because of their witting or unwitting complicity with that world of entrepreneurship. If the addresser succeeds in overcoming the commercial spirit that surrounds her public orations, she may regain the sympathy of the addressee, and if the latter senses the sincerity of these female performers, he can accept their ideas more easily. A woman's speech in public spaces, including television, can be convincing if it is not intended to create a show or make a spectacle on the basis of the gender of the speaker. The audience may, therefore, appreciate the content of the speech and applaud the efforts of the speaker to remain free and unexploited while condemning the manipulated and controlled speakers.

Woman's persuasive talk on podiums and stages recovers the image of the female public performer as an object. Woman's activity and public visibility mirror her new role in society; it goes against the old absolutes of patriarchy which dispel women from all public areas. The materiality of the female performer should not be measured by her beauty or physical display on the stage but should rather be considered as a display of a project, an ideology or an argument. It should be a public address freed from the cultural consideration of gender; it should be one of understanding, reverence and esteem. Platforms reflect and resonate possibilities for experimentation with gender roles not only through the political and cultural side of the message, but also through the performer's style and presence. A public speech is a sign, a set of messages transferred to people, it is a means of interaction between speakers and their observers. Performers acknowledge the presence of the audience, strive to convince them, gain their admiration, cultivate their approval, get their satisfaction, and expect their interaction with what has been said.

The relationship between the female public speaker and the audience is complicated since the speaker's physical presence can be taken as a presence of a female body rather than a competence. What can efface the gender considerations is the ability of the speaker to fascinate her audience by the power of her performance whereby content and ideas would outshine beauty and physical presence. The female body is thus a mere medium of the message and should not distract the focus of the receiver. The performing woman is thus an accomplished artist who uses her language, gestures, feminine manners, intelligence, hands, dress, costume to persuade the others with her ideas. So we cannot dissociate the face from the brain; the female speaker should be accepted as a whole, as a woman politician. We should focus on the political dimension of the female performance without excluding the female body, for it is the performer's tool of expression and the only means to communicate ideas. The possessive gaze of the male audience should be replaced by an assimilation of the speaker's ideas and public podiums should cease to be legitimate places for voyeurism.

The public exposure of women can be for some men a manikin-like show which confirms the existence of a consumer and consumed. If woman's speech becomes a spectacle, men will be the consumers of the spectacular. Certain female orators are caught up in the experiential delight of being exposed in a bright city or television programs without realizing the danger of the male gaze which can turn them into objects. They may be consumed as new product on which the audience's gaze settles and under whose gaze they can dissolve into a plethora of melodramatic images. A male audience may recreate the image of a political performer or lecturer or religious preacher for the pleasure principle and consequently invalidate the aim of the oration for self-concerned principles, and woman's liberated public performances will then turn into a duplication of the conventional image of woman as a consumed object, allowing men to possess her anew. 


\section{Conclusion}

Women speakers are able to enact effective communications once they use their rhetorical skills and stick to a set of techniques. These techniques consist firstly in theatricality that makes the audience believe in the performer's sincerity, authenticity and spontaneity, second in the verbal communicative action that should be twinned with a strategic action, in addition to the speaker's choice between two alternatives: either the search for consensus, as Habermas believes, or the focus on conflicts and power relations, as Foucault assumes. The female performers can be successful public figures, especially if they employ these tools within a context that can grant them with power to help them persuade their audience. Nonetheless, there is the threat of the body that can be turned into an object of exhibition onstage. The mass media reduces woman's political performances to the realm of pleasure while equating feminist performers with vocalists, rope-dancers or even prima donnas. The spectacular may distort the content of the message and makes it a bodily display while vulgarizing the content of the public address and focusing on corporeality (the voice, appearance, gestures) instead. If the media does well in publicizing the spectacular side of the performance, it will attract more audience, thus generate more money. The more the performer is presented as an object of show or a source of delight, the more she will be a source of money. The price that women can pay to enter the public sphere is that they can enter it as commodities, accept their images in posters and photographs, and allow men to lend them an inferior gaze. Female presenters and advertisers, coaches, lecturers can be worked and produced by the media representatives or sponsors or producers.

However, the danger of being repossessed by the audience can be avoided if women speakers succeed in persuading their audience and inviting them to meditate and verify the validity of their ideas. They have to be cautious in political and economic matters to avoid the threat of self-effacement and self-destruction. In order to vanquish the male gaze, the female public speaker should have a reflecting gaze whose rays would confront the fixating one. The speaker should mesmerize her audience, present herself as a lofty creature who places herself at the center of the discourse. When she speaks, she has to be powerful on the stage, narcissistic in her love of her own sex and in command of her audience. Woman is not solely consumed but is herself a consumer, possessor of commodities, subject rather than object. In this context, the performer may commodify her audience and consume them by a constitutive gaze which reformulates her subjectivity. Woman's narcissism and self-esteem make her resist objectification through her refusal of man's entrepreneurship and her deconstruction of the commercial intentions of the mass media and the world of publicity.

\section{References}

[1] Aston, E and G. Savona (1991). The Theatre as Sign-System: A Semiotics of Text and Performance. London: Routledge.
[2] Benveniste, E. (1971). "Analytical philosophy and language." Problems in General Linguistics, trans. M. Elizabeth Meek. Miami: U of Miami P, pp. 231-38.

[3] Bowlby, R. (1985). Just Looking: Consumer Culture in Dreiser, Gissing, and Zola. London: Methuen.

[4] Butler, J. (1993). Bodies that Matter: On the Discursive Limits of "Sex." New York: Routledge.

[5] Calhouned, C. (1999). Ed. Habermas and the Public Sphere. Cambridge: The MIT Press.

[6] Erickson, Y. (2003). "Defining political performance with Foucault and Habermas: strategic and communicative action." Theatricality. T. Davis and T. Postlewait (Eds.). Cambridge: Cambridge University Press.

[7] Foucault, M. (11 March 1976). "Society must be defended." Lectures at the Collège de France: 1975-76, trans. D. Macey. M. Bertain and A. Fontana, Eds. Penguin Books, pp. 239-264.

[8] Foucault, M. (1979). Discipline and Punishment: The Birth of the Prison, trans. A. Sheridan. New York: Random House.

[9] France, P. (1965). Racine's Rhetoric. Oxford: Clarendon Press.

[10] French, J. R. P. and B. Raven. (1959). "Bases of social power." Studies in Social Power. D. Cartwright (Ed.). Ann Arbor: University of Michigan, pp. 150-167.

[11] Habermas, J. (1991). The Structural Transformation of the Public Sphere: An Inquiry into a Category of Bourgeois Society, trans. T. Burger with F. Lawrence. Cambridge: MIT Press.

[12] Ingram, D. (2005). "Foucault and Habermas." The Cambridge Companion to Foucault, G. Gutting (Ed.). Cambridge: Cambridge University Press, pp. 215-261.

[13] Kennedy, G. A. (1980). Classical Rhetoric and its Christian and Secular Tradition from Ancient to Modern Times. London: Croom Helm.

[14] Leith, D. and Myerson. G. (1989). The Power of Address: Explorations in Rhetoric. London: Routledge.

[15] Lukes, S. (2004). Power: A Radical View, 2nd ed. London: Palgrave Macmillan.

[16] Lukes, S. and L. Haglund (April 2005). "Power and luck." European Journal of Sociology, 46 (1): 45-66.

[17] Merriam Webster Online. Merriam Webster.

[18] Nikitina, A. (2011). Successful Public Speaking. Arina Nikitina $\&$ bookboon. com. Academic Transfer.

[19] Ryan, M. P. (1999). "Gender and public access: women's politics in nineteenth-century America." Habermas and the Public Sphere. C. Calhoun (Ed.). Cambridge: The MIT Press.

[20] Toffler, A. (1991). Powershift: Knowledge, Wealth, and Violence at the Edge of the $21^{\text {st }}$ Century. New York: Bantam Books.

[21] Tookey, H. (2003). Anais Nin; Fictionality and femininity: Playing a Thousand Roles. Oxford: Clarendon Press.

[22] Vosquil, L. M. (2004). Acting Naturally: Victorian Theatricality and Authenticity. Virginia: University of Virginia Press. 